\title{
INOVA
}

Working Paper

\# 596

\section{CONFLICTS OF INTEREST IN THE UNDERWRITING OF IPOS AND PRICE STABILIZATION}

2015

NOVA

School

of Business

\& Economics

Shaping

powerful

minds

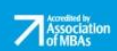

Antonio Gledson de Carvalho João Amaro de Matos Douglas Beserra Pinheiro Marcio de Sa Mello 


\title{
CONFLICTS OF INTEREST IN THE UNDERWRITING OF IPOS AND PRICE STABILIZATION
}

\author{
Antonio Gledson de Carvalho* \\ School of Business at São Paulo \\ Fundação Getulio Vargas
}

\author{
Douglas Beserra Pinheiro ${ }^{* * *}$ \\ Grupo Recovery
}

\author{
João Amaro de Matos ** \\ Nova School of Business and Economics \\ Universidade Nova de Lisboa \\ and \\ School of Business at São Paulo \\ Fundação Getulio Vargas \\ Marcio de Sa Mello****
Brazilian Federal Senate
}

Draft: June 2015

\begin{abstract}
: banks that supply capital and simultaneously underwrite securities for the same clients may benefit themselves or their clients at the expenses of investors by overpricing securities. We investigate this issue by analyzing price stabilization and short-term returns of IPOs. Our analysis suggests that equity-conflicted underwriters overprice IPOs and use price stabilization to disguise overpricing. The same does not happen with loan-conflicted underwriters. We also show that the partial adjustment phenomenon may result from price stabilization, since it disappears after the stabilization is over.
\end{abstract}

Key words: Universal Banking, conflict of interest, underwriting, IPO, price stabilization, aftermarket short covering, partial adjustment

JEL classification: G24

*FGV-EAESP, Av Nove de Julho, 2029, $9^{\circ}$ andar, Sala 912, São Paulo, SP, Brasil, 01332-000. Email: gledson.carvalho@fgv.br. Tel: (5511) 3799-7767. ${ }^{* *}$ Nova School of Business and Economics, Campus de Campolide, Lisboa, 1099-032. Email: amatos@ novasbe.pt. Tel: (351) 213-822-723. ${ }^{* * *}$ Email: dpinheiro@gruporecovery.com. We are thankful for invaluable comments from Charles Calomiris, Igor Cunha, John Graham and Rafael Matta; seminar participants at Universidade Nova de Lisboa and InsperSP; and 2014 Brazilian Financial and 2015 Lubrafin meetings. We acknowledge Pedro Aprigio, Humberto Gallucci Netto, Gabriel Macedo and Joelson Sampaio for their excellent research assistance. De Carvalho acknowledges financial support from $\mathrm{CNPq}$ and Fapesp and Pinheiro from CAPES and GV-Pesquisa. 


\section{1 - Introduction}

The year 2004 saw a resurgence of initial public offerings in Brazil after more than a decade of IPO drought. There was an unusual flow of IPOs until the global financial crisis in 2008 drew the market to a halt. This IPOs wave occurred in a poorly regulated market: many firms received either equity or debt capital from their future underwriters to fund growth and, thus, take advantage of such window. However, it was not until January 2008 that the National Association of Investment Banks (ANBID) included in its Self-Regulation Code a clause forcing underwriters to disclose existing equity or debt conflicts of interest (ANBID, 2008). In June 2008, rumors ${ }^{1}$ began relating the poor performance of Brazilian IPOs to conflict of interest. As response, in March 2009 ANBID amended its code by requiring a second non-conflicted underwriter in the cases of significant conflict of interest (10 percent of equity capital or more than 20 percent of proceeds dedicated to debt repayment).

The literature is not conclusive on how opportunistically banks behave in the presence of either equity or debt conflict of interest. Banks may profit by distributing overvalued securities, but concern with reputation and consequent loss in future businesses could prevent them from engaging in such behavior. Whether concern with reputation is enough to prevent opportunistic behavior has remained an empirical question (Calomiris and Pornrojnangkool, 2009, provide a comprehensive review of this literature).

Loan-conflicted relationship and subsequent underwriting of debt securities have been extensively studied (in the US: Ang and Richardson, 1994; Kroszner and Rajan, 1994; Puri, 1996, 1999; Gande, Puri, Saunders, and Walter, 1997; and Roten and Mullineaux, 2002; and in Japan: Hamao and Hoshi, 2002; Konishi, 2002; Takaoka and McKenzie, 2006; and Kang and Liu, 2007). Overall, there is no evidence of opportunistic behavior, suggesting that the potential loss in reputation is enough to prevent

\footnotetext{
${ }^{1}$ In Brazil's IPO Rush Hits Rough Patch on the first page of The Wall Street Journal of June 20, 2008, one reads: "Two thirds of IPOs are now trading below their offering price. Some investors are blaming the banks that brought the deals to market, saying they cashed in on the frenzy for emerging markets by rushing to take unprepared companies public. Along the way, say investors, banks engaged in questionable practices including lending some companies large sums before taking them public and collecting extra fees on opening day."
} 
opportunism. However, this result may derive from two factors: the relatively weak incentive to misprice when there is loan conflict and the lack of opportunity to disguise mispricing in the underwriting of debt securities.

The existing models on conflicts of interest in underwriting (Kanatas and Qi, 1998 and 2003; Puri, 1999; and Rajan, 2002) focus on loan-conflicted relationships. We are not aware of any model focusing on equity-based conflict and do not provide one. Nonetheless, incentives for shirking may be stronger for equity as compared to loan-based conflict. The return that banks receive from loans does not depend on the price of the securities that their clients subsequently issue, whereas the return on equity does. For instance, in an equity offering, the higher the issuing price, the less equity dilution current shareholders suffer.

Chances for disguising mispricing are higher in the issuance of equity than debt securities: the cash flow of debt securities is predetermined allowing comparison across issues, there is a rating supplied by an independent agent, and ex post performance (default rate) is observable. Things are different for equity securities: cash flow is not predetermined, the measurement of ex post performance is not straightforward (Ritter, 2002) and the price stabilization process allows underwriters to manipulate price in the short run and, thus, disguise overpricing.

Studies on loan-conflict and equity in the underwriting of IPOs do not present conclusive evidence of conflict of interest. Outside the U.S., Ber, Yafeh, and Yosha (2001), Schenone (2004), and Santos, da Silveira, and Barros (2011) focus on short-term performance (underpricing), while Benzoni and Schenone (2010) focus on long-term. ${ }^{2}$ None of these articles controls for the effect of price stabilization. In the U.S., even though Ljungqvist and Wilhelm $\mathrm{Jr}$ (2003) report the existence of direct equity conflict by underwriters holding equity position in issuing firms, the studies are centered on indirect equity conflict via holdings in venture capital funds. Gompers and Lerner (1999) focus on the existence of conflict, and Li and Masulis (2004) on the size of the stake. None of them finds evidence of conflicts of interest.

\footnotetext{
${ }^{2}$ Ber, Yafeh, and Yosha (2001) report less underpricing for conflicted IPOs, but this result comes from mean comparison, limiting the strength of the conclusions. Schenone (2004) finds that IPOs from firms that had a loan relationship with a possible underwriter show less underpricing, but no difference when firms had a loan relationship with the actual underwriter. Santos, da Silveira, and Barros (2011) do not control for price stabilization.
} 
This article investigates the possibility that conflicted underwriters overprice IPOs and use price stabilization to disguise overpricing. Briefly, in the price stabilization process underwriters short sell shares by borrowing them from the issuers ${ }^{3}$ (overallotment). Subsequently, underwriters cover this position either by buying shares in the secondary market (aftermarket short covering, ASC) or by exercising the greenshoe option. In this way underwriters can repurchase shares when price falls below the issuing price without bearing any loss. This mechanism allows underwriters to manipulate the price in the secondary market, disguising overpricing.

For several reasons Brazil is a good setting to study how conflict of interest affects price stabilization and IPO pricing. First, information on price stabilization is mandatory which allows investigating whether conflict of interest affects price stabilization. We study three aspects of price stabilization: exercise of the overallotment option, the occurrence of price stabilization and its intensity. ${ }^{4}$ Second, the stabilization period for all the IPOs in our sample is of the same length. This allows an analysis of price returns at the end of the stabilization period and thus, isolation of the effect of stabilization on price returns. Third, the sample includes both equity and loan-conflicted IPOs, making it possible to investigate the effect of each of the conflicts.

Our analysis indicates that equity-based conflict has a strong effect on the stabilization process: it increases the probability of full overallotment, occurrence of stabilization and its intensity. Loan-based conflict increases the probability of occurrence, but has no effect on intensity and no clear impact on overallotment. For none of the conflicts we find evidence of overpricing during the stabilization period. However, in the post-stabilization period returns for equity-conflicted IPOs are 8 to 9 percent lower than for non-conflicted ones. We find no evidence of mispricing in loan-conflicted IPOs. These results are robust with respect to the termination date of the stabilization process and the length of the post-stabilization period.

\footnotetext{
${ }^{3}$ In the underwriting contract, issuers give the underwriters the right to borrow shares in excess of the contracted number and to sell them along with the contracted shares at the same price. This clause is called overallotment option.

4 The underwriter is allowed to buy and resell shares during the price stabilization period. Thus, price stabilization may occur with zero net repurchased number of shares (intensity). Thus, occurrence and intensity capture distinct dimensions of price stabilization.
} 
Overall our evidence on price stabilization and short-term results suggests that an equity-based conflict (but not a loan-based) leads underwriters to overprice issues and use price stabilization to disguise this. Such result corroborates our argument that incentives to overprice IPOs are stronger in equity-based than in loan-based relationships. These results have policy implications because they indicate that in some circumstances conflicted investment banks may behave opportunistically and harm investors. The table below summarizes our results:

\begin{tabular}{|c||c|c|c|c|c|}
\hline \hline Affect probability of: & $\begin{array}{c}\text { Full } \\
\text { Overallotment }\end{array}$ & Stabilization & $\begin{array}{c}\text { Stabilization } \\
\text { Intensity }\end{array}$ & Overpricing & $\begin{array}{c}\text { Using Stabilization } \\
\text { to Cover Mispricing }\end{array}$ \\
\hline \hline Loan-conflicted & unclear & Yes & no & no & not likely \\
\hline Equity-conflicted & yes & Yes & yes & yes & yes \\
\hline \hline
\end{tabular}

This article is organized as follows: Section 2 describes our data and variables. Section 3 explains our methodology. Section 4 presents our results. Section 5 concludes.

\section{2 -Data and Variables}

Data on offerings come from prospectuses and announcement of end of distribution available at the homepages of Comissao de Valores Mobiliarios (CVM), Companhia Brasileira Liquidacao e Custodia (CBLC), and BMFBovespa (former Bovespa). ${ }^{5}$ Announcements of end of distribution provide details on overallotment, aftermarket short covering (ASC: number of shares repurchased and resold), and allocation of shares across investor classes. Price quotations come from Economatica ${ }^{\circledR}$.

Our initial sample consists of all 106 IPOs that occurred at Bovespa from Jan/2004 to Jun/2008. Before 2004 virtually there were no IPOs in Brazil (De Carvalho and Pennacchi, 2012). After June 2008 IPOs were subject to the self-regulation imposed by ANBID requiring a non-conflicted co-managing underwriter in the case of significant conflict of interest. From the initial sample we drop one IPO conducted on the best-efforts basis, one for which there was no provision for price stabilization, and six that were distributed exclusively to institutional investors. Thus, our final sample consists of 98 IPOs.

Loan conflict is identified by a loan of at least US\$150,000 from one leading underwriter or a parent company. Equity conflict is identified by at least five percent pre-

\footnotetext{
${ }^{5}$ www.cvm.gov.br, www.cblc.com.br and www.bmfbovespa.com.br.
} 
IPO ownership of one leading underwriter. Among the IPOs that we excluded there was only one loan-conflicted IPO and no equity-conflicted IPO. In our sample 39 IPOs were either equity or loan conflicted: 31 were loan-conflicted, 15 were equity-conflicted, and 7 were both. Because an equity conflict presents stronger incentives for opportunism than a loan conflict, we classify issues that have both conflicts as equity-conflicted and refer to those that are only loan-conflicted as loan-only.

Variables characterizing the price stabilization process are: Overallotment, a dummy variable indicating when the overallotment was exercised at its maximum established level; Stabilization (occurrence of stabilization), a dummy variable indicating the occurrence of ASC; and Stabilization Intensity, the ratio of ASC to overallotment (if there were no ASC or if shares repurchased were entirely resold, this variable takes a value zero; if the overallotment was entirely covered by repurchasing shares, it takes value one). ${ }^{6}$ Table 1 lists all variables.

Variables characterizing the issue are: Size, natural logarithm of the offering (issuing price multiplied by the number of shares excluding overallotment and hot issue options); Syndicate, number of underwriters in the syndicate; Underwriter, the Carter and Manaster (1990) index for underwriter reputation, updated by Loughran and Jay Ritter (2004) for the 2001-2004 period. Our measure corresponds to the index of the most reputable member of the syndicate. Underwriters not ranked were assigned the lowest rate, i.e., 1.1; Price, offer price; Price Range, difference between the maximum and minimum price in initial filling range divided by their average; Price Revision, offer price minus the midpoint of the initial filling range divided by the latter; Retail Investors, number of retail investors that received allocation in the IPO; and Institutional Investors, number of institutional investors that received shares in the $\mathrm{IPO}^{7}$.

Table 2 presents summary statistics for the whole sample. The average overallotment was 14.2 percent. The overallotment was below its possible maximum value of 15 percent in only 13 IPOs. ASC occurred in 55 IPOs (56 percent of the 98 IPOs). On average 34.4 percent of the overallotment was covered in the aftermarket. In 10 cases

\footnotetext{
${ }^{6}$ In our sample, all IPOs had an established maximum overallotment of 15 percent. Only 13 IPOs were not overalloted at this upper limit. Because of such mild cross-sectional variation, it became convenient to define a binary variable.

${ }^{7}$ International plus domestic institutional investors. Domestic institutional investors, such as underwriters and partners of the issuing company are excluded.
} 
the underwriter repurchased shares and resold all of them during the stabilization period (the intensity of the stabilization was zero). In 53 IPOs the overallotment was entirely covered by exercise of the greenshoe option (55.2 percent of the 96 overalloted IPOs). In 20 IPOs the overallotment was entirely covered in the aftermarket (20.8 percent of the overalloted IPOs). The average of the exercised greenshoe in relation to the initial offering was 9.31 percent. The hot-issue option was exercised in only 15 IPOs, and in all of these cases the overallotment was exercised at its maximum level, suggesting a pecking order: Underwriters first overallot, and then exercise the hot-issue option. In only three IPOs for which the hot-issue was exercised was there ASC ( $20 \%$ of the cases).

Table 3 reports correlations. In general correlations are relatively low (below 0.4) and of no statistical significance. As expected, correlation coefficients among variables measuring demand (Institutional Investors, Retail Investors, and Price Revision) are relatively high, but the highest is 0.643 (between Institutional Investors and Price Revision), suggesting that these variables capture distinct aspects of the demand.

\section{3 - Methodology}

The existing models on price stabilization (Benveniste, Busab, and Wilhelm, 1996; Chowdhry and Nanda, 1996; Prabhala and Puri, 1998; and Zhang, 2004) predict that stabilization depends on the riskiness and the demand for the issue. Thus, our econometric model to analyze the effect of conflict of interest on price stabilization has the following specification:

$$
\text { Dependent }=\beta_{0}+\beta_{1} C I+\beta_{2} \vec{R}+\beta_{3} \vec{D}+\beta_{4} U+\varepsilon,
$$

where

Dependent can be Overallotment, Stabilization, or Stabilization Intensity.

$C I$ is a dummy variable indicating existent conflict of interest between the issuer and its underwriter (Equity, Loan-only or none);

$\vec{R}$ is a vector of variables characterizing the riskiness of issue; and

$\vec{D}$ is a vector of variables representing the demand for the issue.

Since Overallotment and Stabilization are binary variables, estimations use probit regressions. As Intensity of Stabilization is bounded between 0 and $100 \%$, estimations use Tobit regressions. Variables possibly related to the riskiness of the issue are: Size, 
Syndicate, Price, and Price Range. Variables associated to the demand are: Price Revision, Retail Investors, and Institutional Investors.

To estimate the effect of conflict of interest on returns we use a balanced panel:

$$
r_{i t}=\beta_{0}+\beta_{1} C I_{i}+\beta_{2} M_{i t}+\beta_{3} X_{i}+\varepsilon_{i t},
$$

where

$r_{i t}$ is the price return for firm $i$ on the trading day $\mathrm{t}$ measured with respect to the issuing price;

$M_{i t}$ is the return of the Bovespa index over the $t$ first trading days of the issue $i$; and $X_{i}$ is a time-invariant vector of characteristics of the IPO.

$\beta_{1}$ gauges the excess return of conflicted IPOs relative to non-conflicted IPOs over the sample period. If conflicted IPOs underperform non-conflicted ones, $\beta_{1}$ must be negative. We estimate Model 2 using random effects with White (1980) robust errors. We estimate Model 2 over the stabilization and post-stabilization periods separately.

A third model aims at capturing the impact of the termination of price stabilization on the returns of conflicted IPOs:

$$
r_{i t}=\beta_{0}+\beta_{1} C I_{i}+\beta_{2} C I_{i} \times \text { Stabilization }_{i t}+\beta_{3} M_{i t}+\delta X_{i}+\varepsilon_{i t},
$$

where

Stabilization $_{i t}$ is a dummy variable indicating the stabilization period for issue $i$.

$\beta_{2}$ measures the difference in returns of conflicted IPOs during and after the price stabilization period. If returns are lower in the post-stabilization period $\beta_{2}$ is positive. The difference in returns in the post-stabilization period between conflicted and nonconflicted IPOs is given by $\beta_{1}$. The difference in returns during the price stabilization period between both groups of IPO is given by $\beta_{1}+\beta_{2}$. We estimate Model 3 using fixed effects and random effects with firm clusters. Both estimations use White (1980) robust errors.

Identifying the termination of the price stabilization period is crucial for Models 2 and 3. Fortunately, all IPOs in our sample had a specified stabilization period of 30 running days. This represents from 20 to 22 trading days, depending on holidays and the day of the week on which the IPO took place. Price stabilization can also in fact end before the deadline. Since we cannot precisely identify when price stabilization is over, 
we replicate the analysis using three possible termination dates: the $18^{\text {th }}, 20^{\text {th }}$ and $22^{\text {nd }}$ trading days.

\section{4 - Empirical Results}

\section{1 - Univariate analysis}

Univariate analysis in Table 2 anticipates our main results of the effect of conflict of interest on price stabilization. Equity conflict affects price stabilization in its three dimensions, while loan-only conflict affects just the probability of occurrence of ASC. Equity conflict increases overallotment: on average the overallotment of equityconflicted IPOs is 14.9 versus 13.8 percent for non-conflicted ones (difference statistically significant at the one percent level); increases the probability of ASC: 73 versus 44 percent (difference statistically significant at the five percent level); and increases the intensity stabilization: in average 57 percent of the overallotment is covered in the ASC versus 44 percent (difference statistically significant at the five percent level). The only consequence of loan-conflict is an increase in the probability of ASC: 75 versus 44 percent (difference statistically significant at the one percent level).

Univariate analysis does not indicate any statistically significant effect of conflict of interest on price returns. Over the price stabilization period average market adjusted returns for equity, loan-only and non-conflicted IPOs are 4.7, 3.8 and 5.5 percent respectively. Over the post-stabilization period these returns are 1.2, 4.8 and 5.0 percent. One should note that after the stabilization, returns on equity conflicted IPOs drop by 3.5 percent, while returns on loan-only conflict increase by 1.0 percent.

Price revision is the only covariate for which there is statistically significant difference between loan-only and non-conflicted IPOs: -8.5 versus -2.3 percent. Equityconflicted IPOs on average have larger syndicates (2.4 versus 1.9 members) and lower prices (BR\$ 2.71 versus 2.96).

\section{2 - Price stabilization}

Table 4 presents our econometric analysis of the determinants of price stabilization (Model 1). Panel A focuses on the overallotment (whether it is exercised at its maximum possible value). Equity conflict of interest affects overallotment. The coefficient 0.922 on Equity in Regression 1 is statistically significant at the 10 percent 
level. The coefficient of 0.836 on Loan-only is not statistically significant, but the tstatistic of 1.64 suggests that the lack of significance may be due to sample size. In Regressions 2 and 3, coefficients on variables Equity and Loan-only are smaller and lose statistical significance (t-statistics are near 1.3). This is so because the estimated effect for both variables is positive. Thus, the omission of one variable raises the average value of the residual group, lowering the coefficient and the statistical significance of the other variable. Besides conflicts of interest, ex-ante demand is the only other factor affecting overallotment. Price Revision and Retail Investors have positive coefficients that are statistically significant at the 10 and 5 percent levels respectively.

Panel B focuses on the determinants of occurrence of ASC (Stabilization). Both variables Equity and Loan-only have positive signs and are statistically significant in all regressions. In regression 4 the coefficient 1.503 on Equity is statistically significant at the one percent level and the coefficient 0.954 on Loan-only is statistically significant at the five percent level. Once again, since both coefficients are positive, the omission of one variable in Regressions 5 and 6 reduces the size and statistical significance of the other. Nevertheless, both coefficients remain statistically significant.

Several characteristics of the IPO also affect the occurrence of price stabilization. Variable Size bears a negative coefficient that is statistically significant at the five or one percent level (five percent in Regressions 5 and 6 and one percent in Regression 4). The size of the syndicate has similar effect, even though it is statistically significant only in Regressions 4 and 6. The coefficient on the reputation of the underwriter is positive and statistically significant at the ten percent level in Regressions 4 and 6. Variable Price Range has positive and statistically significant coefficients in Regressions 5 and 6 . The coefficient on Price is not statistically significant in any regression. Variables associated with ex-ante demand are also important to predict stabilization. Price Revision is negative and statistically significant at the five or one percent level. This seems to be a consequence of the partial adjustment phenomenon detected by Hanley (1993). When price is adjusted upward, it subsequently increases, reducing the need for stabilization. Finally, the sign associated with Retail Investor is positive and statistically significant at the five or one percent level. This can be due to the presence of flippers among retail investors, who trade their shares immediately after the distribution, and force price downward. 
Finally, Panel $\mathrm{C}$ focuses on the determinants of the intensity of stabilization. The coefficient on Equity is positive and statistically significant at the five percent level in Regressions 7 and 9. Distinctively, t-statistics for the coefficients on Loan-Only in Regressions 7 and 8 are very low (0.63 and -0.18), suggesting that a loan conflict does not affect the intensity of the stabilization at all. Syndicate and Price Revision are the only other variables that bear statistical significance. Both variables have negative coefficients that are statistically significant at the ten or five percent level.

Overall, our analysis indicates that conflict of interest affects price stabilization. A loan conflict affects only the likeliness of stabilization but not its intensity, suggesting that it does not motivate underwriters to resort to price stabilization to disguise mispricing. Equity conflict increases the probability of the issue being fully overallotted and stabilized, and the intensity of the stabilization suggesting that stabilization could be used to disguise overpricing. But before jumping to that conclusion one needs to analyze its effects on short-term returns.

\section{3 - Short-term returns}

Table 5 reports estimations of price returns with respect to the issuing price over several periods (Mode1 1). Regressions 1, 2, and 3 focus on underpricing (first-day returns). Conflict of interest seems to have no impact on underpricing; the coefficients on variables Equity and Loan-only are always positive, very small and not statistical significant (t-statistics below 0.7). This result differs from that of Schenone (2004) who finds that loan-conflicted IPOs are less underpriced than non-conflicted ones. The only variables with explanatory power over underpricing are those related to the reputation of the underwriter and the demand. The coefficient on Underwriter is negative and statistically significant at the one percent level. The coefficient on Price Revision is positive and statistically significant at the five or one percent level (confirming the partial adjustment phenomenon of Hanley, 1993). The number of retail investors receiving allocation decreases the underpricing, while the number of institutional investors increases it. Both variables are statistically significant at the five or one percent level.

Regressions 4, 5, and 6 cover the price stabilization period. As in the underpricing regressions, the variables associated with conflict of interest bear no statistical significance. The coefficient on Equity becomes negative and its t-statistics increases to 
near 1.5. The lack of statistical significance may be due to small sample size. The coefficient on Loan-only remains positive with low t-statistics (below 0.8). As expected, the coefficient around 0.6 on the market index is statistically significant at the one percent level (t-statistic above 8.0). Results for the other variables are similar to those in Regressions 1-3.

Regressions 7-12 focus on the post-stabilization period. We use two poststabilization windows: from the $19^{\text {th }}$ to the $30^{\text {th }}$ trading days (Regressions 7-9) and from the $23^{\text {rd }}$ to the $30^{\text {th }}$ (Regressions 10-12). The main result that emerges is that returns on equity-conflicted IPOs are negative and statistically significant and those on Loanconflicted are positive but not statistically significant. In Regression 7 the coefficient on Equity is -0.0813 , indicating equity conflicted IPOs underperforms non-conflicted ones by 8.13 percent. This result is statistically significant at the 10 percent level. In Regression 8 , the relative underperformance of equity-conflicted IPOs increases to 8.64 percent. The underperformance measured in Regression 8 is higher than in Regression 7 because Regression 8 omits Loan-only. Consequently, the performance of equity-conflicted IPOs is compared to the pool of loan-conflicted and non-conflicted IPOs. As the coefficient on Loan-only is positive, its omission increases the average return on the residual group, exacerbating the underperformance of equity-conflicted IPOs. Regressions 7 and 9 confirm that loan-conflict does not cause IPOs to be overpriced. In fact, they are underpriced, even though the result is not statistically significant.

Results in Regressions 10-12 are similar to those in Regressions 7-9 both in terms of magnitude and statistical significance, indicating that our results are robust with respect to the termination date for price stabilization.

Table 5 also shows that Price Revision loses statistical significance immediately after the end of the price stabilization period. This suggests that the partial adjustment may result from price stabilization: when underwriters revise price upwards they use price stabilization to prevent prices from falling below the issuing price, truncating the return distribution at zero and, thus, generating positive returns.

Table 6 analyzes the impact of the termination of price stabilization on returns (Model 3). Our analysis includes the usual controls, but we report only the coefficients on the dummy variables Equity and Loan-only and their interactions with the dummy 
variable indicating the stabilization period. Odd-numbered regressions use random effects and even-numbered regressions, fixed effects. The sample in Panel A includes both stabilized and non-stabilized IPOs. Regression 1 uses random effects and assumes that stabilization terminates on the $18^{\text {th }}$ trading day.

The coefficient of -0.0692 on Equity, statistically significant at the 10 percent level, indicates that equity conflicted IPOs underperform non-conflicted IPOs by 6.92 percent in the post-stabilization period. The coefficient of 0.0362 on the interaction between Equity and Stabilization, statistically significant at the five percent level, indicates that in the post-stabilization period the price of equity-conflicted IPOs falls on average by 3.62 percent. In Regression 2 the use of fixed effects only slightly changes coefficients and t-statistics. One should note that the coefficient on Loan-only and its interaction with Stabilization are positive but very small and not statistically significant. Therefore, loan-conflicted IPOs do not underperform non-conflicted ones in both periods and there is no significant change in price at the termination of stabilization. Regressions 3-8 consider distinct termination dates for price stabilization. Regressions 3 and 4 assume the $20^{\text {th }}$ trading day; 5 and 6 , the $22^{\text {nd }}$; and 7 and 8 assumes that the $17^{\text {th }}$ and also excludes the $18^{\text {th }}$ to $22^{\text {nd }}$ trading days. Change in termination dates only marginally affects coefficients and statistical significance.

The sample in Panel B retains only IPOs that were stabilized. The effect of termination of price stabilization on the returns of equity-conflicted IPOs becomes stronger. For example, From Regression 1 to Regression 9 the coefficient on the interaction of Equity and Stabilization increases to 0.0517 and remains statistically significant, indicating that returns at the end of stabilization period for equity conflicted IPOs fall by 5.17 percent. One should note that the coefficient on Loan-only increases to 0.0253 becoming closer to significance level (t-statistics is 1.40 ). The coefficient on its interaction with variable Stabilization is very close to zero in terms of both size and statistical significance. Therefore, if any effect exists, loan-conflicted IPOs overperform non-conflicted ones and price stabilization has no effect on their returns. This result is in lines with that of Kang and Liu (2007) who find that underwriters discount the price of loan-conflicted bonds. Once again, the use of fixed effects (Regression 10) or the variation of the termination date (Regressions 11 to 16) only slightly changes the coefficients on both parameters and their associated t-statistics. 
Figure 1 illustrates our main results on short-term returns. It plots adjusted returns with respect to issuing price until the $40^{\text {th }}$ trading day. A vertical line marks the $20^{\text {th }}$ trading day, around which stabilization terminates. Market-adjusted returns for the pool of non-conflicted and loan-conflicted IPOs are fairly stable around five percent. For equity-conflicted IPOs, the initial underpricing is around eight percent; during the price stabilization period, returns are similar to those of non-conflicted IPOs. After the end of price stabilization, returns of equity-conflicted IPOs drop significantly.

Overall our analysis indicates that a loan conflict does not affect price stabilization and does not cause mispricing of IPOs. Differently, equity conflict causes IPOs to be overpriced. Furthermore, equity conflict also intensifies the stabilization efforts. These results suggest that underwriters overprice equity-conflicted IPOs and use price stabilization to disguise such overpricing.

\section{5 - Conclusion}

Commercial banks acting as underwriters can potentially benefit themselves or their corporate clients at the expense of investors. By harming investors, banks run the risk of losing their investors clients and, consequently, the capacity to place issues. Whether concern with reputation is enough to discourage price manipulation has remained an empirical matter. A variety of authors have examined banks that provide customer loans and subsequently underwrite their debt securities without finding evidence of conflicts of interest.

We argue that equity vis-à-vis debt conflict gives the bank stronger incentives to manipulate prices. Equity-conflicted underwriters can reduce ownership dilution by overpricing the issue and thus increase returns on their equity investment. Debt-conflicted underwriters cannot increase the return on their debt investment by overpricing issues, since the cash flow of debt securities is predetermined. We also argue that issuance of equity vis-à-vis debt securities gives the underwriter more room to disguise mispricing. Debt securities have predetermined cash flows, an independent agent opinion (rating) and easily observable ex-post performance (default rate). Equity securities have variable cash flow, no independent agent opinion, no easily measured ex post performance. Additionally, the price stabilization mechanism allows underwriters to manipulate prices in the secondary market and thus, camouflage overpricing in the short run. Even though 
the underwriting of equity securities by equity-conflicted banks is common in many countries, only few articles studied this case, without finding evidence of harm to investors. The absence of control for price stabilization may explain such results, mainly because in most countries underwriters are not bound to disclose information on price stabilization.

Brazil offers a good setting for studying the issuance of equity securities. An institutional feature forces underwriters to disclose information on the price stabilization process and on the ex-ante demand for the IPO. Furthermore, all IPOs have the same price stabilization period of 30 running days. These features allow us to study whether conflict of interest affects price stabilization and the behavior of short-term returns of conflicted IPOs at the end of the stabilization period.

Our analysis indicates that loan-based conflict does not distort piece stabilization and does not cause IPOs overpricing. Differently, equity-based conflict distorts price stabilization: it increases the chances of the issue being fully overalloted and stabilized, as well as the intensity of the stabilization. We also find that equity-conflicted IPOs are overpriced, but that overpricing is observable only after the termination of the stabilization process. These findings suggest that price stabilization may be used to disguise mispricing.

We also find that the partial adjustment phenomenon detected by Hanley (1993) is observable only during the price stabilization period. Variable Price Revision loses statistical significance immediately after the end of the stabilization period. This suggests that partial adjustment may result from price stabilization: when underwriters revise price upwards they use price stabilization to prevent prices from falling below the issuing price, truncating the distribution of return and, thus, generating positive returns.

\section{6 - References}

ANBID, Associação Nacional de Bancos de Investimento, 2008, Código de AutoRegulação da ANBID para Ofertas Públicas de Distribuição e Aquisição de Valores Imobiliários.

ANBID, Associação Nacional de Bancos de Investimento, 2009, Código ANBID pde Regulação e Melhores Práticas para as Ofertas Públicas de Distribuição e Aquisição de Valores Imobiliários. 
Ang, James and Terry Richardson, 1994, The Underwriting Experiences of Commercial Bank Affiliates Prior to the Glass-Steagall Act: a Re-examination of Evidence of Passage of the Act. Journal of Banking and Finance 18, 351-395.

Benveniste, Lawrence M., Walid Y. Busab, and William J. Wilhelm Jr., 1996, Price Stabilization as a Bonding Mechanism in New Equity Issues. Journal of Financial Economics 42, 223-255.

Benzoni, Luca, and Carola Schenone, 2010, Conflict of Interest and Certification in the US IPO Market. Journal of Financial Intermediation 19, 235-254.

Ber, Hedva, Yishay Yafeh, and Oved Yosha, 2001, Conflict of Interest in Universal Banking: Bank Lending, Stock Underwriting, and Fund Management. Journal of Monetary Economics 47, 189-218.

Calomiris, Charles, and Thanavut Pornrojnangkool, 2009, Relationship Banking and the Pricing of Financial Services. Journal of Financial Services Research 35, 189-224.

Carter, Richard, and Steven Manaster, 1990, Initial Public Offerings and Underwriter Reputation. Journal of Finance 45, 1045-1067.

Chowdhry, Bhagwan, and Vikram Nanda, 1996, Stabilization, Syndication, and Pricing of IPOs. Journal of Financial and Quantitative Analysis 31, 25-42.

De Carvalho, Antonio G., and George Pennacchi 2012, Can a Stock Exchange Improve Corporate Behavior? Evidence from Firms' Migration to Premium Listings in Brazil. Journal of Corporate Finance 18, 883-903.

Gande, Amar, Manju Puri, Anthony Saunders, and Ingo Walter, 1997, Bank Underwriting of Debt Securities: Modern Evidence. Review of Financial Studies 10, 1175-1202.

Gompers, Paul, and Josh Lerner, 1999, Conflict of Interest in the Issuance of Public Securities: Evidence from Venture Capital. Journal of Law and Economics 42, 1-28.

Hamao, Yasushi, and Takeo Hoshi, 2002, Bank Underwriting of Corporate Bonds Evidence from Japan after the Financial System Reform of 1993. Working Paper, University of Southern California.

Hanley, Kathleen W., 1993, The Underpricing of Initial Public Offerings and the Partial Adjustment Phenomenon. Journal of Financial Economics 34, 231-251.

Kanatas, George, and Jianping Qi, 1998, Underwriting by Commercial Banks: Incentive Conflicts, Scope Economies, and Project Quality. Journal of Money, Credit and Banking 30, 119-133.

Kanatas, George, and Jianping Qi, 2003, Integration of Lending and Underwriting: Implications of Scope Economies. Journal of Finance 58, 1167-1191.

Kang, Jun-Koo and Wei-Lin Liu, 2007, Is Universal Banking Justified? Evidence from Bank Underwriting of Corporate Bonds in Japan. Journal of Financial Economics 84, 142-186. 
Konishi, Masaru, 2002, Bond Underwriting by Banks and Conflicts of Interest: Evidence from Japan during the Pre-War Period. Journal of Banking and Finance 26, 767-793.

Kroszner, Randalland Raghuram Rajan, 1994, Is the Glass-Steagall Act Justified? A Study of the U.S. Experience with Universal Banking before 1933. American Economic Review 84, 810-832.

Li, Xi, and Ronald Masulis, 2004, Venture Capital Investments by IPO Underwriters: Certification or Conflict of Interest? Working paper, Vanderbilt University.

Ljungqvist, Alexander and William Wilhelm Jr., 2003, IPO pricing in the Dot-com bubble. Journal of Finance 58, 723-752.

Ljungqvist, Alexander P., Tim Jenkinson, and William J. Wilhelm Jr., 2003, Global Integration of Primary Equity Markets: The Role of U.S. Banks and U.S. Investors. The Review of Financial Studies 16 (1), 63-99.

Loughran, Timothy and Jay Ritter, 2004, Why Has IPO Underpricing Changed Over Time?. Financial Management 33, 5-37.

Prabhala, N. R., and Manju Puri, 1998, How Does Underwriter Price Support Affect IPOs? Empirical Evidence. Available at: http://ssrn.com/abstract=95948. Access on Sept/14/2007.

Puri, Manju, 1996, Commercial Banks as Underwriters: Implications for the Going Public Process. Journal of Financial Economics 54, 133-163.

Puri, Manju, 1999, Commercial Banks in Investment Banking: Conflict of Interest or Certification Role? Journal of Financial Economics 40, 373-401.

Rajan, Raghuram, 2002, An Investigation into the Economics of Extending Bank Powers. Journal of Emerging Market Finance 1, 125-156.

Ritter, Jay, 2002, A Review of IPO Activity, Pricing and Allocations. Journal of Finance 57 (1), 1795-1828.

Rock, Kevin, 1986, Why New Issues are Underpriced. Journal of Financial Economics $15,187-212$.

Roten, Ivan, and Donald Mullineaux, 2002, Debt Underwriting by Commercial BankAffiliated Firms and Investment Banks: More Evidence. Journal of Banking and Finance 26, 689-718.

Santos, Rafael Liza, Alexandre Di Miceli da Silveira, and Lucas Ayres Barros, 2011, PreIPO Lending from Underwriters and Negative ex post Performance: Evidence of Conflicts of Interest in the Brazilian 2004-2007 IPO Wave. Presented at: II World Finance Conference, Rhodes, Greece.

Schenone, Carola, 2004, The Effect of Banking Relationships on the Firm's IPO Underpricing. Journal of Finance 59, 2903-2958. 
Takaoka, Sumiko, and Colin R. McKenzie, 2006, The Impact of Bank Entry in the Japanese Corporate Bond Underwriting Market. Journal of Banking and Finance 30, 59-83.

White, Halbert., 1980, A Heteroskedasticity-Consistent Covariance Matrix Estimator and a Direct Test of Heteroskedasticity. Econometrica 48 (4), 817-838.

Zhang, Donghang, 2004, Why Do IPO Underwriters Allocate Extra Shares when They Expect to Buy Them Back? Journal of Financial and Quantitative Analysis 39 (3), 571-594. 


\section{Table 1}

\section{Variables Description}

\begin{tabular}{|l|l|}
\hline \multicolumn{1}{|c|}{$r_{i t}$} & return with respect to the issuing price of firm $i$ on the trading day $t$ \\
\hline Loan-Only & $\begin{array}{l}\text { Dummy variable indicating that the firms received loan but not equity investment } \\
\text { from the underwriter. }\end{array}$ \\
\hline Equity & $\begin{array}{l}\text { Dummy variable indicating that the firms received equity investment from the } \\
\text { underwriter. }\end{array}$ \\
\hline Size & Natural logarithm of the initial offering times the issuing price (in Brazilian reais) \\
\hline Syndicate & Number of underwriters in the syndicate \\
\hline Underwriter & $\begin{array}{l}\text { Carter and Manaster's index for underwriters reputation (1990), updated in } \\
\text { Loughran and Ritter (2004) for the period between 2001 and 2004. The rate } \\
\text { ranked were assigned the lowest rate, i.e., 1.1. }\end{array}$ \\
\hline Price & Natural logarithm of the offer price. \\
\hline Price Range & $\begin{array}{l}\text { Difference between the maximum and minimum price in initial filling range divided } \\
\text { by the midpoint of the filling range }\end{array}$ \\
\hline Price Revision & Offer price minus the midpoint of the initial filling divided by the latter. \\
\hline Retail Investors & Number of retail investors that received shares in the IPO. \\
\hline Institutional & $\begin{array}{l}\text { Number of institutional investors that received shares in the IPO (international } \\
\text { investors plus domestic institutional investors. domestic institutional investors, } \\
\text { such as underwriters and partners of the issuing company were excluded) }\end{array}$ \\
\hline Investors & Dummy variable indicating the stabilization period. \\
\hline Stabilization &
\end{tabular}


Table 2

\section{Descriptive Statistics}

Sample consists of 98 IPO at Bovespa between 2004 and 2008, being 15 equity-conflicted, 24 loan but not equity conflicted and 49 non-conflicted. Variables are Overallotment: as proportion of the maximum possible value established in the prospectus; Stabilization: dummy variable indicating that there was ASC; Stabilization Intensity: number of shares repurchased in the ASC divided by the overallotment, Underpricing return on the first trading day with respect to the issuing price; Average return $x-y$ is the average of the market adjusted returns between days $\mathrm{x}$ and y; Size: initial offering times the issuing price in BR\$; Syndicate: number of underwriters in the syndicate; Underwriter: Carter and Manaster (1990) index for underwriters reputation updated by Loughran and Ritter (2004); Price: natural logarithm of the offer price; Price Range: difference between the maximum and minimum price in initial filling range divided their average; Price Revision: the offer price minus the midpoint of the initial filling range normalized by the latter; Retail Investors: number of retail investors that received shares in the IPO; and Institutional Investors: number of institutional investors that received shares in the IPO. Standard-deviations or tstatistics for difference in means are in parentheses.

\begin{tabular}{|c|c|c|c|c|c|c|}
\hline & Full Sample & $\begin{array}{l}\text { Equity- } \\
\text { conflicted }\end{array}$ & $\begin{array}{l}\text { Loan-only- } \\
\text { conflicted }\end{array}$ & Neither & $\begin{array}{l}\text { Difference } \\
\text { Neither - } \\
\text { Loan }\end{array}$ & $\begin{array}{l}\text { Difference } \\
\text { Neither - } \\
\text { Equity }\end{array}$ \\
\hline Overallotment & $\begin{array}{l}14 \% \\
(2.3)\end{array}$ & $\begin{array}{l}14.9 \% \\
(0.1 \%)\end{array}$ & $\begin{array}{l}14.4 \% \\
(1.9 \%)\end{array}$ & $\begin{array}{l}13.8 \% \\
(3.1 \%)\end{array}$ & $\begin{array}{l}-0.6 \% \\
(1.07)\end{array}$ & $\begin{array}{l}-1.2 \% * * * \\
(2.84)\end{array}$ \\
\hline Stabilization & $\begin{array}{c}56 \% \\
(55 / 98)\end{array}$ & $\begin{array}{c}73 \% \\
(11 / 15)\end{array}$ & $\begin{array}{c}75 \% \\
(18 / 24)\end{array}$ & $\begin{array}{c}44 \% \\
(26 / 49)\end{array}$ & $\begin{array}{l}-31 \% * * * \\
(2.77)\end{array}$ & $\begin{array}{c}-29 \% * * \\
(2.16)\end{array}$ \\
\hline $\begin{array}{l}\text { Stabilization } \\
\text { Intensity }\end{array}$ & $\begin{array}{l}34 \% \\
(44 \%)\end{array}$ & $\begin{array}{l}57 \% \\
(43 \%)\end{array}$ & $\begin{array}{l}41 \% \\
(45 \%)\end{array}$ & $\begin{array}{l}28 \% \\
(42 \%)\end{array}$ & $\begin{array}{l}-13 \% \\
(1.21)\end{array}$ & $\begin{array}{c}-29 \% * * \\
(2.34)\end{array}$ \\
\hline Underpricing & $\begin{array}{c}5.5 \% \\
(10.3 \%)\end{array}$ & $\begin{array}{c}8.2 \% \\
(16.2 \%)\end{array}$ & $\begin{array}{l}3.6 \% \\
(6.3 \%)\end{array}$ & $\begin{array}{c}5.6 \% \\
(0.097 \%)\end{array}$ & $\begin{array}{l}2.0 \% \\
(1.11)\end{array}$ & $\begin{array}{l}-2.6 \% \\
(0.59)\end{array}$ \\
\hline Average Return 1-19 & $\begin{array}{l}5.0 \% \\
(0.117)\end{array}$ & $\begin{array}{c}4.7 \% \\
(0.168)\end{array}$ & $\begin{array}{l}3.8 \% \\
(0.09)\end{array}$ & $\begin{array}{l}5.5 \% \\
(0.112)\end{array}$ & $\begin{array}{l}1.7 \% \\
(0.72)\end{array}$ & $\begin{array}{l}0.8 \% \\
(0.18)\end{array}$ \\
\hline $\begin{array}{l}\text { Average Return 20- } \\
\text { 30 }\end{array}$ & $\begin{array}{l}4.3 \% \\
(0.144)\end{array}$ & $\begin{array}{l}1.2 \% \\
(0.21)\end{array}$ & $\begin{array}{l}4.8 \% \\
(0.123)\end{array}$ & $\begin{array}{l}5.0 \% \\
(0.133)\end{array}$ & $\begin{array}{l}0.1 \% \\
(0.04)\end{array}$ & $\begin{array}{l}3.8 \% \\
(0.66)\end{array}$ \\
\hline Size & $\begin{array}{l}712 \\
(826)\end{array}$ & $\begin{array}{c}1159 \\
(1569)\end{array}$ & $\begin{array}{c}562 \\
(198)\end{array}$ & $\begin{array}{c}659 \\
(684)\end{array}$ & $\begin{array}{c}96 \\
(0.98)\end{array}$ & $\begin{array}{l}-500 \\
(1.21)\end{array}$ \\
\hline Syndicate & $\begin{array}{c}2.01 \\
(0.805)\end{array}$ & $\begin{array}{c}2.40 \\
(0.828)\end{array}$ & $\begin{array}{c}2.04 \\
(0.690)\end{array}$ & $\begin{array}{c}1.89 \\
(0.824)\end{array}$ & $\begin{array}{l}-0.14 \\
(0.80)\end{array}$ & $\begin{array}{c}-0.50 * * \\
(2.09)\end{array}$ \\
\hline Underwriter & $\begin{array}{c}8.847 \\
(0.841)\end{array}$ & $\begin{array}{c}9.001 \\
(0)\end{array}$ & $\begin{array}{c}8.876 \\
(128.71)\end{array}$ & $\begin{array}{c}8.79 \\
(63.56)\end{array}$ & $\begin{array}{l}-0.078 \\
(0.50)\end{array}$ & $\begin{array}{l}-0.20 \\
(1.46)\end{array}$ \\
\hline Price & $\begin{array}{c}2.88 \\
(0.408)\end{array}$ & $\begin{array}{c}2.71 \\
(0.358)\end{array}$ & $\begin{array}{c}2.80 \\
(0.403)\end{array}$ & $\begin{array}{c}2.96 \\
(0.409)\end{array}$ & $\begin{array}{l}0.158 \\
(1.62)\end{array}$ & $\begin{array}{l}0.25 * * \\
(2.31)\end{array}$ \\
\hline Price Range & $\begin{array}{c}0.215 \\
(0.051)\end{array}$ & $\begin{array}{c}0.227 \\
(0.039)\end{array}$ & $\begin{array}{c}0.221 \\
(0.051)\end{array}$ & $\begin{array}{c}0.209 \\
(0.054)\end{array}$ & $\begin{array}{l}-0.011 \\
(0.91)\end{array}$ & $\begin{array}{l}-0.018 \\
(1.46)\end{array}$ \\
\hline Price Revision & $\begin{array}{l}-0.035 \\
(0.158)\end{array}$ & $\begin{array}{c}0.003 \\
(0.203)\end{array}$ & $\begin{array}{l}-0.085 \\
(0.144)\end{array}$ & $\begin{array}{l}-0.023 \\
(0.149)\end{array}$ & $\begin{array}{l}0.062 * \\
(1.77)\end{array}$ & $\begin{array}{l}-0.026 \\
(0.46)\end{array}$ \\
\hline Retail Investors & $\begin{array}{c}12,718 \\
(26,646)\end{array}$ & $\begin{array}{c}14,177 \\
(16,481)\end{array}$ & $\begin{array}{l}10,014 \\
(6,920)\end{array}$ & $\begin{array}{c}13,447 \\
(33,148)\end{array}$ & $\begin{array}{c}3432 \\
(0.75)\end{array}$ & $\begin{array}{l}-729 \\
(0.12)\end{array}$ \\
\hline $\begin{array}{l}\text { Institutional } \\
\text { Investors }\end{array}$ & $\begin{array}{c}313 \\
(252)\end{array}$ & $\begin{array}{c}419 \\
(447)\end{array}$ & $\begin{array}{c}252 \\
(108)\end{array}$ & $\begin{array}{c}311 \\
(211)\end{array}$ & $\begin{array}{l}58.17 \\
(1.60)\end{array}$ & $\begin{array}{l}-108 \\
(0.91)\end{array}$ \\
\hline
\end{tabular}

$*, * *$, and $* * *$ respectively indicate significance levels at $10 \%, 5 \%$, and $1 \%$ levels. 
Table 3

\section{Correlations}

Equity: dummy variable indicating that the firms received equity investment from the underwriter; Loan-Only: dummy variable indicating that the firms received loan but not equity investment from the underwriter; Size: natural logarithm of the initial offering times the issuing price (in Brazilian reais); Syndicate: number of underwriters in the syndicate; Underwriter: Carter and Manaster (1990) index for underwriters reputation updated by Loughran and Ritter (2004); Price: natural logarithm of the offer price; Price Range: difference between the maximum and minimum price in initial filling range divided by the midpoint of the filling range; Price Revision: offering price minus the midpoint of the initial filling divided by the latter; Retail Investors: number of retail investors that received shares in the IPO; and Institutional Investors: number of institutional investors that received shares in the IPO. T-statistics are in parentheses.

\begin{tabular}{|c|c|c|c|c|c|c|c|c|c|}
\hline & $\begin{array}{l}\text { Loan- } \\
\text { Only } \\
\end{array}$ & Equity & Size & Syndicate & Underwriter & Price & $\begin{array}{c}\text { Price } \\
\text { Range } \\
\end{array}$ & $\begin{array}{c}\text { Price } \\
\text { Revision } \\
\end{array}$ & $\begin{array}{c}\text { Retail } \\
\text { Investors } \\
\end{array}$ \\
\hline Equity & $\begin{array}{c}-0.242 * * * \\
(0.01)\end{array}$ & 1 & & & & & & & \\
\hline Size & $\begin{array}{l}-0.055 \\
(0.59)\end{array}$ & $\begin{array}{c}0.196 * \\
(0.05)\end{array}$ & 1 & & & & & & \\
\hline Syndicate & $\begin{array}{l}0.022 \\
(0.82)\end{array}$ & $\begin{array}{c}0.207 * * \\
(0.04)\end{array}$ & $\begin{array}{c}0.498 * * * \\
(0.00)\end{array}$ & 1 & & & & & \\
\hline Underwriter & $\begin{array}{l}0.019 \\
(0.85)\end{array}$ & $\begin{array}{l}0.078 \\
(0.45)\end{array}$ & $\begin{array}{l}0.164 \\
(0.11)\end{array}$ & $\begin{array}{l}0.154 \\
(0.13)\end{array}$ & 1 & & & & \\
\hline Price & $\begin{array}{l}-0.115 \\
(0.25)\end{array}$ & $\begin{array}{c}-\mathbf{0 . 1 7 8} * \\
(0.08)\end{array}$ & $\begin{array}{c}0.192^{*} \\
(0.06)\end{array}$ & $\begin{array}{l}0.011 \\
(0.91)\end{array}$ & $\begin{array}{l}0.072 \\
(0.47)\end{array}$ & 1 & - & & \\
\hline Price Range & $\begin{array}{l}0.065 \\
(0.52)\end{array}$ & $\begin{array}{l}0.105 \\
(0.31)\end{array}$ & $\begin{array}{c}-0.094 \\
(0.35)\end{array}$ & $\begin{array}{c}-0.199 * * \\
(0.04)\end{array}$ & $\begin{array}{l}0.046 \\
(0.65)\end{array}$ & $\begin{array}{c}0.272 * * * \\
(0.01)\end{array}$ & 1 & & \\
\hline Price Revision & $\begin{array}{c}-0.184 * \\
(0.07)\end{array}$ & $\begin{array}{l}0.100 \\
(0.32)\end{array}$ & $\begin{array}{c}\mathbf{0 . 3 2 1} * * * * \\
(\mathbf{0 . 0 0})\end{array}$ & $\begin{array}{l}0.095 \\
(0.35)\end{array}$ & $\begin{array}{l}-0.017 \\
(0.86)\end{array}$ & $\begin{array}{c}0.448 * * * * \\
(0.00)\end{array}$ & $\begin{array}{c}0.01 \\
(0.92)\end{array}$ & 1 & \\
\hline Retail Investors & $\begin{array}{l}-0.058 \\
(0.57)\end{array}$ & $\begin{array}{l}0.023 \\
(0.82)\end{array}$ & $\begin{array}{c}0.516 * * * \\
(0.00)\end{array}$ & $\begin{array}{c}0.434 * * * \\
(0.00)\end{array}$ & $\begin{array}{l}0.005 \\
(0.95)\end{array}$ & $\begin{array}{l}0.061 \\
(0.55)\end{array}$ & $\begin{array}{r}-0.154 \\
(0.13)\end{array}$ & $\begin{array}{c}0.31 * * * \\
(0.00)\end{array}$ & 1 \\
\hline Institutional investors & $\begin{array}{l}-0.137 \\
(0.18)\end{array}$ & $\begin{array}{c}0.179 * \\
(0.07)\end{array}$ & $\begin{array}{c}\mathbf{0 . 6 8} * * * * \\
(0.00)\end{array}$ & $\begin{array}{c}0.47 * * * \\
(0.00)\end{array}$ & $\begin{array}{l}0.051 \\
(0.62)\end{array}$ & $\begin{array}{c}\mathbf{0 . 3 5 3} * * * \\
(\mathbf{0 . 0 0})\end{array}$ & $\begin{array}{c}-0.218 * * \\
(0.03)\end{array}$ & $\begin{array}{c}0.643 * * * \\
(0.00)\end{array}$ & $\begin{array}{c}0.55 * * * * \\
(\mathbf{0 . 0 0 )}\end{array}$ \\
\hline
\end{tabular}

$*, * *$, and $* * *$ respectively indicate significance levels at $10 \%, 5 \%$, and $1 \%$ levels. 
Table 4

\section{Conflict of Interest and Price Stabilization Process}

The dependent variable are: dummy variable indicating that the overallotment was fully exercised (Panel A), dummy variable indicating that there was ASC (Panel B) and the number of shares repurchased in the ASC divided by the overallotment (Panel C). Reported values are marginal effects. The variables are Equity: dummy variable indicating the existence of equity-conflict; LoanOnly: dummy variable indicating loan but not equity-conflict of interest; Size: natural logarithm of the final offering value in BR\$; Syndicate: number of underwriters in the syndicate; Underwriter: Carter and Manaster (1990) index for underwriters reputation updated by Loughran and Ritter (2004); Price: natural logarithm of the offer price; Price Range: difference between the maximum and minimum price in initial filling range divided their average; Price Revision: the offer price minus the midpoint of the initial filling range normalized by the latter; Retail Investors: number of retail investors that received shares in the IPO (in thousands); and Institutional Investors: number of institutional investors that received shares in the IPO (in thousands). Estimators obtained using White (1980) robust errors. T-Statistics are in parentheses. Sample in Panel A is 98 IPOs. Sample in Panels B and C consists of 96 IPOs for which there was overallotment.

\begin{tabular}{|c|c|c|c|c|c|c|c|c|c|}
\hline \multirow[t]{2}{*}{ Regression } & \multicolumn{3}{|c|}{$\begin{array}{c}\text { Panel A } \\
\text { Overallotment (probit) }\end{array}$} & \multicolumn{3}{|c|}{$\begin{array}{c}\text { Panel B } \\
\text { Stabilization Occurrence (probit) }\end{array}$} & \multicolumn{3}{|c|}{$\begin{array}{c}\text { Panel C } \\
\text { Stabilization Intensity (tobit) }\end{array}$} \\
\hline & (1) & (2) & (3) & (4) & (5) & (6) & (7) & (8) & (9) \\
\hline Equity & $\begin{array}{l}0.922 * \\
(1.67)\end{array}$ & & $\begin{array}{l}0.647 \\
(1.23)\end{array}$ & $\begin{array}{c}1.503 * * * \\
(3.20)\end{array}$ & & $\begin{array}{c}1.165 * * \\
(2.51)\end{array}$ & $\begin{array}{c}1.255 * * \\
(2.44)\end{array}$ & & $\begin{array}{c}1.166 * * \\
(2.33)\end{array}$ \\
\hline Loan-Only & $\begin{array}{l}0.836 \\
(1.64)\end{array}$ & $\begin{array}{l}0.641 \\
(1.35)\end{array}$ & & $\begin{array}{c}0.954 * * \\
(2.30)\end{array}$ & $\begin{array}{c}0.658 * \\
(1.67)\end{array}$ & & $\begin{array}{l}0.250 \\
(0.63)\end{array}$ & $\begin{array}{l}-0.073 \\
(-0.18)\end{array}$ & \\
\hline Size & $\begin{array}{l}-4.160 \\
(-0.50)\end{array}$ & $\begin{array}{l}-2.347 \\
(-0.27)\end{array}$ & $\begin{array}{l}-4.445 \\
(-0.51)\end{array}$ & $\begin{array}{c}-17.79 * * * \\
(-2.73)\end{array}$ & $\begin{array}{c}-14.99 * * \\
(-2.15)\end{array}$ & $\begin{array}{c}-16.46 * * \\
(-2.55)\end{array}$ & $\begin{array}{l}-7.773 \\
(-1.04)\end{array}$ & $\begin{array}{l}-6.498 \\
(-0.86)\end{array}$ & $\begin{array}{l}-7.647 \\
(-1.03)\end{array}$ \\
\hline Syndicate & $\begin{array}{l}-0.236 \\
(-0.98)\end{array}$ & $\begin{array}{l}-0.219 \\
(-0.92)\end{array}$ & $\begin{array}{l}-0.189 \\
(-0.85)\end{array}$ & $\begin{array}{c}-0.496 * * \\
(-2.18)\end{array}$ & $\begin{array}{l}-0.348 \\
(-1.57)\end{array}$ & $\begin{array}{c}-0.418 * \\
(-1.95)\end{array}$ & $\begin{array}{c}-0.528 * * \\
(-2.03)\end{array}$ & $\begin{array}{l}-0.401 \\
(-1.54)\end{array}$ & $\begin{array}{l}-0.499 * \\
(-1.93)\end{array}$ \\
\hline Underwriter & dropped & dropped & dropped & $\begin{array}{c}0.352^{*} \\
(1.76)\end{array}$ & $\begin{array}{l}0.391 \\
(1.46)\end{array}$ & $\begin{array}{c}0.333 * \\
(1.80)\end{array}$ & $\begin{array}{l}0.456 \\
(1.03)\end{array}$ & $\begin{array}{l}0.567 \\
(1.01)\end{array}$ & $\begin{array}{l}0.419 \\
(1.12)\end{array}$ \\
\hline Price Range & $\begin{array}{l}-0.922 \\
(-0.24)\end{array}$ & $\begin{array}{l}-0.374 \\
(-0.10)\end{array}$ & $\begin{array}{l}-0.331 \\
(-0.09)\end{array}$ & $\begin{array}{l}4.471 \\
(1.58)\end{array}$ & $\begin{array}{c}5.368 * \\
(1.92)\end{array}$ & $\begin{array}{c}5.314 * \\
(1.89)\end{array}$ & $\begin{array}{l}3.302 \\
(0.96)\end{array}$ & $\begin{array}{l}3.896 \\
(1.11)\end{array}$ & $\begin{array}{l}3.638 \\
(1.05)\end{array}$ \\
\hline Price & $\begin{array}{l}-0.201 \\
(-0.44)\end{array}$ & $\begin{array}{l}-0.402 \\
(-0.90)\end{array}$ & $\begin{array}{l}-0.346 \\
(-0.75)\end{array}$ & $\begin{array}{l}0.033 \\
(0.07)\end{array}$ & $\begin{array}{l}-0.227 \\
(-0.51)\end{array}$ & $\begin{array}{l}-0.043 \\
(-0.10)\end{array}$ & $\begin{array}{l}-0.367 \\
(-0.71)\end{array}$ & $\begin{array}{l}-0.702 \\
(-1.38)\end{array}$ & $\begin{array}{l}-0.392 \\
(-0.78)\end{array}$ \\
\hline Price-Revision & $\begin{array}{c}2.569 * \\
(1.95)\end{array}$ & $\begin{array}{c}2.453^{*} \\
(1.86)\end{array}$ & $\begin{array}{l}2.210 \\
(1.64)\end{array}$ & $\begin{array}{c}-3.437 * * \\
(-2.45)\end{array}$ & $\begin{array}{c}-2.844 * * \\
(-2.30)\end{array}$ & $\begin{array}{c}-3.878 * * * * \\
(-2.77)\end{array}$ & $\begin{array}{c}-3.018 * * \\
(-2.11)\end{array}$ & $\begin{array}{c}-2.717 * \\
(-1.90)\end{array}$ & $\begin{array}{c}-3.134 * * \\
(-2.17)\end{array}$ \\
\hline Retail Investors & $\begin{array}{c}0.0001 * * \\
(2.27)\end{array}$ & $\begin{array}{c}0.0001 * * \\
(2.22)\end{array}$ & $\begin{array}{c}0.0001 * * \\
(2.42)\end{array}$ & $\begin{array}{c}0.0000 * * * \\
(2.69)\end{array}$ & $\begin{array}{c}0.0000 * * \\
(2.06)\end{array}$ & $\begin{array}{c}0.0000 * * * \\
(2.38)\end{array}$ & $\begin{array}{l}0.000 \\
(1.43)\end{array}$ & $\begin{array}{l}0.000 \\
(0.93)\end{array}$ & $\begin{array}{l}0.000 \\
(1.37)\end{array}$ \\
\hline Institutional Investors & $\begin{array}{c}-0.0006 \\
(-0.62)\end{array}$ & $\begin{array}{c}-0.0006 \\
(-0.59)\end{array}$ & $\begin{array}{c}-0.0000 \\
(-0.05)\end{array}$ & $\begin{array}{r}-0.0013 \\
(-1.44)\end{array}$ & $\begin{array}{c}-0.0011 \\
(-1.28)\end{array}$ & $\begin{array}{c}-0.0007 \\
(-0.87)\end{array}$ & $\begin{array}{l}-0.001 \\
(-0.69)\end{array}$ & $\begin{array}{l}-0.001 \\
(-0.60)\end{array}$ & $\begin{array}{l}-0.001 \\
(-0.59)\end{array}$ \\
\hline Constant & $\begin{array}{l}14.00 \\
(0.57)\end{array}$ & $\begin{array}{c}9.17 \\
(0.36)\end{array}$ & $\begin{array}{l}15.19 \\
(0.59)\end{array}$ & $\begin{array}{c}49.85 * * * \\
(2.60)\end{array}$ & $\begin{array}{c}41.65 * * \\
(2.00)\end{array}$ & $\begin{array}{c}46.13 * * \\
(2.43)\end{array}$ & $\begin{array}{l}20.15 \\
(0.91)\end{array}$ & $\begin{array}{l}16.22 \\
(0.71)\end{array}$ & $\begin{array}{l}20.11 \\
(0.92)\end{array}$ \\
\hline P-value (F-test) & 0.0484 & 0.0529 & 0.101 & 0 & 0 & 0 & 0.0924 & 0.0825 & 0.0661 \\
\hline
\end{tabular}

$*, * *$, and $* * *$ respectively indicate significance levels at $10 \%, 5 \%$, and $1 \%$ levels. 
Table 5

(Panel A)

Conflict of Interest and IPO Returns over Different Periods

Panel analysis. The dependent variable is the daily stock return with respect to the issuing price over different time intervals. The explanatory variables are Equity: dummy variable indicating that the underwriter is equity-conflicted, Loan-Only: dummy variable indicating that the underwriter is loan but not equity-conflicted, Market Index: return on the Ibovespa index with respect to its value on the IPO date, Size: natural logarithm of the initial offering times the issuing price (in Brazilian reais), Syndicate: number of underwriters in the syndicate, Underwriter: Carter and Manaster's index for underwriters reputation (1990), updated by Jay Ritter for the period between 2001 and 2004, Price natural logarithm of the offering price, Price Range: difference between the maximum and minimum price in initial filling range divided by the midpoint of the filling range, Price Revision: offering price minus the midpoint of the initial filling divided by the latter, Retail Investors: number of retail investors that received shares in the IPO (in thousands), and Institutional Investors: number of institutional investors that received shares in the IPO (in thousands). Regressions 1-3 are cross-section; 4-9 were obtained using random effects with White (1980) robust errors and firm clusters. T-statistics are in parentheses.

\begin{tabular}{|c|c|c|c|c|c|c|c|c|c|c|c|c|}
\hline \multirow{2}{*}{$\begin{array}{c}\text { Period } \\
\text { Regression }\end{array}$} & \multicolumn{3}{|c|}{ Underpricing } & \multicolumn{3}{|c|}{ Days 1-18 } & \multicolumn{3}{|c|}{ Days 19-30 } & \multicolumn{3}{|c|}{ Days 23-30 } \\
\hline & (1) & $(2)$ & (3) & (4) & (5) & (6) & (7) & (8) & (9) & (10) & (11) & (12) \\
\hline Equity & $\begin{array}{c}0.0077 \\
(0.36)\end{array}$ & $\begin{array}{c}0.0037 \\
(0.19)\end{array}$ & & $\begin{array}{c}-0.0388 \\
(-1.43)\end{array}$ & $\begin{array}{c}-0.0412 \\
(-1.56)\end{array}$ & & $\begin{array}{c}-0.0813 * \\
(-1.93)\end{array}$ & $\begin{array}{c}-0.0864 * * \\
(-2.06)\end{array}$ & & $\begin{array}{c}-0.0852 * \\
(-1.86)\end{array}$ & $\begin{array}{c}-0.0907 * * \\
(-2.00)\end{array}$ & \\
\hline Loan-Only & $\begin{array}{c}0.0115 \\
(0.74)\end{array}$ & & $\begin{array}{c}0.0098 \\
(0.71)\end{array}$ & $\begin{array}{c}0.0069 \\
(0.35)\end{array}$ & & $\begin{array}{c}0.0151 \\
(0.79)\end{array}$ & $\begin{array}{c}0.0149 \\
(0.52)\end{array}$ & & $\begin{array}{c}0.0321 \\
(1.09)\end{array}$ & $\begin{array}{c}0.0160 \\
(0.51)\end{array}$ & & $\begin{array}{c}0.0340 \\
(1.08)\end{array}$ \\
\hline Market Index & $\begin{array}{c}0.6348 \\
(1.39)\end{array}$ & $\begin{array}{c}0.5852 \\
(1.30)\end{array}$ & $\begin{array}{c}0.6213 \\
(1.37)\end{array}$ & $\begin{array}{c}\mathbf{0 . 6 0 9 9} * * * \\
(\mathbf{8 . 0 2})\end{array}$ & $\begin{array}{c}\mathbf{0 . 6 0 9 9} * * * \\
(\mathbf{8 . 0 2})\end{array}$ & $\begin{array}{c}0.6108 * * * \\
(8.02)\end{array}$ & $\begin{array}{c}\mathbf{0 . 6 3 2 1} * * * \\
(5.77)\end{array}$ & $\begin{array}{c}\mathbf{0 . 6 3 1 8} * * * \\
\quad(5.77)\end{array}$ & $\begin{array}{c}\mathbf{0 . 6 4 0 3} * * * \\
\quad(5.88)\end{array}$ & $\begin{array}{l}0.5982 * * * \\
\quad(5.24)\end{array}$ & $\begin{array}{c}0.5976 * * * \\
(5.24)\end{array}$ & $\begin{array}{c}0.6107 * * * \\
(5.41)\end{array}$ \\
\hline Size & $\begin{array}{c}-0.0110 \\
(-0.54)\end{array}$ & $\begin{array}{c}-0.0104 \\
(-0.51)\end{array}$ & $\begin{array}{c}-0.0102 \\
(-0.51)\end{array}$ & $\begin{array}{l}0.0007 \\
(0.03)\end{array}$ & $\begin{array}{c}0.0009 \\
(0.04)\end{array}$ & $\begin{array}{c}-0.0028 \\
(-0.13)\end{array}$ & $\begin{array}{c}-0.0130 \\
(-0.44)\end{array}$ & $\begin{array}{c}-0.0125 \\
(-0.42)\end{array}$ & $\begin{array}{c}-0.0203 \\
(-0.68)\end{array}$ & $\begin{array}{c}-0.0197 \\
(-0.61)\end{array}$ & $\begin{array}{c}-0.0192 \\
(-0.59)\end{array}$ & $\begin{array}{c}-0.0274 \\
(-0.84)\end{array}$ \\
\hline Syndicate & $\begin{array}{l}0.0014 \\
(0.12)\end{array}$ & $\begin{array}{c}0.0020 \\
(0.17)\end{array}$ & $\begin{array}{c}0.0019 \\
(0.17)\end{array}$ & $\begin{array}{c}0.0002 \\
(0.01)\end{array}$ & $\begin{array}{l}0.0006 \\
(0.04)\end{array}$ & $\begin{array}{c}-0.0028 \\
(-0.19)\end{array}$ & $\begin{array}{c}0.0172 \\
(0.80)\end{array}$ & $\begin{array}{c}0.0182 \\
(0.85)\end{array}$ & $\begin{array}{c}0.0109 \\
(0.53)\end{array}$ & $\begin{array}{c}0.0214 \\
(0.93)\end{array}$ & $\begin{array}{c}0.0225 \\
(0.98)\end{array}$ & $\begin{array}{l}0.0147 \\
(0.67)\end{array}$ \\
\hline Underwriter & $\begin{array}{c}-0.0171 * * * \\
(-4.44)\end{array}$ & $\begin{array}{c}-0.0170 * * * * \\
(-4.42)\end{array}$ & $\begin{array}{c}-0.0169 * * * \\
(-4.50)\end{array}$ & $\begin{array}{c}-0.0151 * * * * \\
(-3.25)\end{array}$ & $\begin{array}{c}-0.0150 * * * \\
(-3.25)\end{array}$ & $\begin{array}{c}-0.0159 * * * \\
(-3.32)\end{array}$ & $\begin{array}{c}-0.0131 * * \\
(-2.08)\end{array}$ & $\begin{array}{c}-0.0130 * * \\
(-2.05)\end{array}$ & $\begin{array}{c}-0.0148 * * \\
(-2.26)\end{array}$ & $\begin{array}{c}-0.0135 * * \\
(-1.98)\end{array}$ & $\begin{array}{c}-0.0134 * * \\
(-1.97)\end{array}$ & $\begin{array}{c}-0.0153 * * \\
(-2.17)\end{array}$ \\
\hline Price & $\begin{array}{c}0.0149 \\
(0.65)\end{array}$ & $\begin{array}{c}0.0139 \\
(0.61)\end{array}$ & $\begin{array}{l}0.0129 \\
(0.61)\end{array}$ & $\begin{array}{l}0.0127 \\
(0.51)\end{array}$ & $\begin{array}{c}0.0120 \\
(0.48)\end{array}$ & $\begin{array}{c}0.0229 \\
(1.01)\end{array}$ & $\begin{array}{l}0.0247 \\
(0.64)\end{array}$ & $\begin{array}{c}0.0233 \\
(0.59)\end{array}$ & $\begin{array}{c}0.0463 \\
(1.20)\end{array}$ & $\begin{array}{c}0.0293 \\
(0.70)\end{array}$ & $\begin{array}{c}0.0278 \\
(0.66)\end{array}$ & $\begin{array}{c}0.0519 \\
(1.24)\end{array}$ \\
\hline Price Range & $\begin{array}{c}-0.1312 \\
(-0.87)\end{array}$ & $\begin{array}{c}-0.1206 \\
(-0.79)\end{array}$ & $\begin{array}{c}-0.1263 \\
(-0.83)\end{array}$ & $\begin{array}{c}0.1430 \\
(0.92)\end{array}$ & $\begin{array}{c}0.1483 \\
(0.94)\end{array}$ & $\begin{array}{c}0.1210 \\
(0.79)\end{array}$ & $\begin{array}{c}0.1781 \\
(0.73)\end{array}$ & $\begin{array}{c}0.1894 \\
(0.77)\end{array}$ & $\begin{array}{c}0.1337 \\
(0.56)\end{array}$ & $\begin{array}{c}0.1864 \\
(0.68)\end{array}$ & $\begin{array}{c}0.1984 \\
(0.72)\end{array}$ & $\begin{array}{c}0.1406 \\
(0.53)\end{array}$ \\
\hline Price Revision & $\begin{array}{c}0.1562 * * * \\
(2.64)\end{array}$ & $\begin{array}{c}0.1513 * * \\
(2.59)\end{array}$ & $\begin{array}{c}0.1575 * * \\
(2.63)\end{array}$ & $\begin{array}{c}0.1431 * \\
(1.95)\end{array}$ & $\begin{array}{c}0.1409 * \\
(1.94)\end{array}$ & $\begin{array}{c}\mathbf{0 . 1 3 4 4} * \\
(1.85)\end{array}$ & $\begin{array}{c}0.0876 \\
(0.70)\end{array}$ & $\begin{array}{c}0.0828 \\
(0.66)\end{array}$ & $\begin{array}{c}0.0697 \\
(0.56)\end{array}$ & $\begin{array}{c}0.0511 \\
(0.37)\end{array}$ & $\begin{array}{c}0.0460 \\
(0.34)\end{array}$ & $\begin{array}{c}0.0326 \\
(0.24)\end{array}$ \\
\hline Retail Investors & $\begin{array}{c}-0.0005^{* * *} \\
(-2.36)\end{array}$ & $\begin{array}{c}-0.0005 * * \\
(-2.42)\end{array}$ & $\begin{array}{c}-0.0005 * * * \\
(-2.74)\end{array}$ & $\begin{array}{c}-0.0007 * * * * \\
(-2.61)\end{array}$ & $\begin{array}{c}-0.0007 * * * * \\
(-2.63)\end{array}$ & $\begin{array}{c}-0.0006 * * \\
(-2.36)\end{array}$ & $\begin{array}{c}-0.0014 * * * * \\
(-3.93)\end{array}$ & $\begin{array}{c}-0.0015 * * * \\
(-3.92)\end{array}$ & $\begin{array}{c}-0.0012 * * * \\
(-3.48)\end{array}$ & $\begin{array}{c}-0.0019 * * * \\
(-4.77)\end{array}$ & $\begin{array}{c}-0.0019 * * * \\
(-4.74)\end{array}$ & $\begin{array}{c}-0.0016 * * * \\
(-4.38)\end{array}$ \\
\hline Institutional Investors & $\begin{array}{c}0.2681 * * * \\
(6.14)\end{array}$ & $\begin{array}{c}0.2685 * * * \\
(6.19)\end{array}$ & $\begin{array}{c}0.2699 * * * \\
(6.32)\end{array}$ & $\begin{array}{c}0.2666^{* * * *} * \\
(5.32)\end{array}$ & $\begin{array}{c}0.2665 * * * \\
(5.31)\end{array}$ & $\begin{array}{c}0.2586 * * * * \\
(5.29)\end{array}$ & $\begin{array}{c}0.2926 * * * * \\
(3.50)\end{array}$ & $\begin{array}{c}0.2924 * * * * \\
(3.48)\end{array}$ & $\begin{array}{c}0.2757 * * * * \\
(3.42)\end{array}$ & $\begin{array}{c}0.3223 * * * * \\
(3.52)\end{array}$ & $\begin{array}{c}\text { 0.3221**** } \\
(3.50)\end{array}$ & $\begin{array}{c}\text { 0.3046**** } \\
(3.46)\end{array}$ \\
\hline Constant & $\begin{array}{c}0.3318 \\
(0.82)\end{array}$ & $\begin{array}{c}0.3226 \\
(0.79)\end{array}$ & $\begin{array}{c}0.3204 \\
(0.80)\end{array}$ & $\begin{array}{c}0.0417 \\
(0.11)\end{array}$ & $\begin{array}{c}0.0390 \\
(0.10)\end{array}$ & $\begin{array}{c}0.0926 \\
(0.23)\end{array}$ & $\begin{array}{c}0.2229 \\
(0.41)\end{array}$ & $\begin{array}{c}0.2170 \\
(0.39)\end{array}$ & $\begin{array}{c}0.3300 \\
(0.60)\end{array}$ & $\begin{array}{c}0.3346 \\
(0.56)\end{array}$ & $\begin{array}{c}0.3282 \\
(0.54)\end{array}$ & $\begin{array}{c}0.4476 \\
(0.74)\end{array}$ \\
\hline Observations & 98 & 98 & 98 & 1,764 & 1,764 & 1,764 & 1,176 & 1,176 & 1,176 & 784 & 784 & 784 \\
\hline $\begin{array}{l}\text { Firms } \\
\text { R-squared }\end{array}$ & $\begin{array}{c}98 \\
0.630\end{array}$ & $\begin{array}{c}98 \\
0.628\end{array}$ & $\begin{array}{c}98 \\
0.630\end{array}$ & $\begin{array}{c}98 \\
0.415\end{array}$ & $\begin{array}{c}98 \\
0.414\end{array}$ & $\begin{array}{c}98 \\
0.404\end{array}$ & $\begin{array}{c}98 \\
0.362\end{array}$ & $\begin{array}{c}98 \\
0.361\end{array}$ & $\begin{array}{c}98 \\
0.342\end{array}$ & $\begin{array}{c}98 \\
0.358\end{array}$ & $\begin{array}{c}98 \\
0.356\end{array}$ & $\begin{array}{c}98 \\
0.339\end{array}$ \\
\hline P-value (F-test) & 0 & 0 & 0 & 0 & $\begin{array}{c}0 .+14 \\
0\end{array}$ & $\begin{array}{c}0 .+45 \\
0\end{array}$ & $\begin{array}{l}0.502 \\
0\end{array}$ & $\begin{array}{l}0.501 \\
0\end{array}$ & 0 & $\begin{array}{l}0 \\
0\end{array}$ & 0 & $\begin{array}{l}0 \\
0\end{array}$ \\
\hline
\end{tabular}

$*, * *$, and $* * *$ respectively indicate significance levels at $10 \%, 5 \%$, and $1 \%$ levels. 


\section{Table 6}

\section{Conflict of Interest and IPO Returns over Time: the Effect of Price Stabilization}

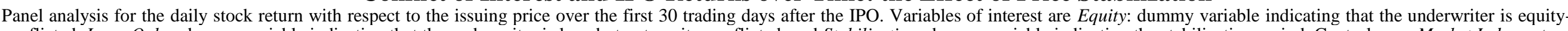

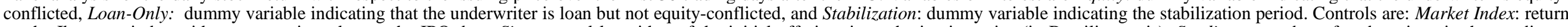

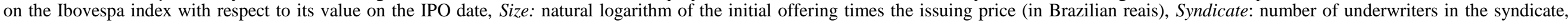

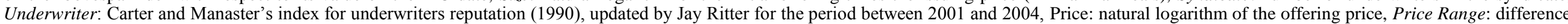

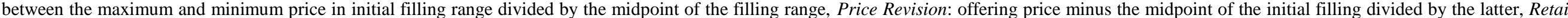

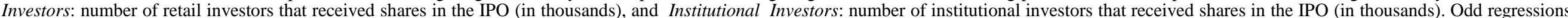
were obtained using random effects with robust errors and firm clusters and even specifications, using fixed effects with robust errors. T-statistics are in parentheses.

Panel A: sample contains stabilized and non-stabilized IPOs

2,940 firm-day observations from 98 IPOs, being 24 loan-only conflicted and 15 equity-conflicted)

\begin{tabular}{|c|c|c|c|c|c|c|c|c|}
\hline End of stabilization: & \multicolumn{2}{|c|}{$18^{\text {Th }}$ day } & \multicolumn{2}{|c|}{$20^{\text {th }}$ day } & \multicolumn{2}{|c|}{$22^{\text {nd }}$} & \multicolumn{2}{|c|}{ Exclude $18-22^{\text {nd }}$ days } \\
\hline Regression & (1) & (2) & (3) & (4) & (5) & (6) & (7) & (8) \\
\hline Equity & $\begin{array}{c}-0.0692 * \\
(-1.81)\end{array}$ & \multirow[b]{2}{*}{$\begin{array}{l}\mathbf{0 . 0 3 6 1} * * \\
(2.02)\end{array}$} & $\begin{array}{c}-0.0707 * \\
(-1.79)\end{array}$ & \multirow[b]{2}{*}{$\begin{array}{c}\mathbf{0 . 0 3 5 0} * \\
(1.81)\end{array}$} & $\begin{array}{c}-0.0721 * \\
(-1.76)\end{array}$ & \multirow[b]{2}{*}{$\begin{array}{c}\mathbf{0 . 0 3 4 0 *} \\
(1.70)\end{array}$} & $\begin{array}{c}-0.0719 * \\
(-1.16)\end{array}$ & \multirow[b]{2}{*}{$\begin{array}{c}\mathbf{0 . 0 3 9 4} * \\
(1.81)\end{array}$} \\
\hline $\begin{array}{l}\text { Equity * Stabilization } \\
\text { Loan-Only }\end{array}$ & $\begin{array}{c}\mathbf{0 . 0 3 6 2} * * \\
(\mathbf{2 . 0 2}) \\
0.0071 \\
(0.35)\end{array}$ & & $\begin{array}{c}\mathbf{0 . 0 3 5 1} * \\
(\mathbf{1 . 8 1}) \\
0.0084 \\
(0.40)\end{array}$ & & $\begin{array}{c}\mathbf{0 . 0 3 4 1 *} \\
(\mathbf{1 . 6 9 )} \\
0.0077 \\
(0.37)\end{array}$ & & $\begin{array}{c}\mathbf{0 . 0 3 9 5 *} \\
(\mathbf{1 . 8 1}) \\
0.0065 \\
(0.32)\end{array}$ & \\
\hline Loan-Only * Stabilization & $\begin{array}{c}0.0106 \\
(0.73)\end{array}$ & $\begin{array}{c}0.0105 \\
(0.73)\end{array}$ & $\begin{array}{c}0.0092 \\
(0.63)\end{array}$ & $\begin{array}{r}0.0091 \\
(0.63)\end{array}$ & $\begin{array}{c}0.0102 \\
(0.71)\end{array}$ & $\begin{array}{c}0.0111 \\
(0.72)\end{array}$ & $\begin{array}{c}0.0130 \\
(0.76)\end{array}$ & $\begin{array}{c}0.0129 \\
(0.76)\end{array}$ \\
\hline $\begin{array}{l}\text { Controls } \\
\text { R-Squared (overall) } \\
\text { F-test (p-value) }\end{array}$ & $\begin{array}{c}\text { Yes } \\
0.381 \\
0\end{array}$ & $\begin{array}{c}\text { Yes } \\
0.240 \\
0\end{array}$ & $\begin{array}{c}\text { Yes } \\
0.380 \\
0\end{array}$ & $\begin{array}{c}\text { Yes } \\
0.238 \\
0\end{array}$ & $\begin{array}{c}\text { Yes } \\
0.380 \\
0\end{array}$ & $\begin{array}{c}\text { Yes } \\
0.237 \\
0\end{array}$ & $\begin{array}{c}\text { Yes } \\
0.378 \\
0\end{array}$ & $\begin{array}{c}\text { Yes } \\
0.234 \\
0\end{array}$ \\
\hline \multicolumn{9}{|c|}{$\begin{array}{l}\text { Panel B: sample contains only stabilized IPOs } \\
\text { tions from } 55 \text { IPOs, being } 18 \text { loan-only conflicted and } 11 \text { equity-conflicted) }\end{array}$} \\
\hline End of stabilization: & \multicolumn{2}{|c|}{$18^{\text {th }}$ day } & \multicolumn{2}{|c|}{$20^{\text {th }}$ day } & \multicolumn{2}{|c|}{$22^{\text {nd }}$ day } & \multicolumn{2}{|c|}{ Exclude 18-22 ${ }^{\text {nd }}$ days } \\
\hline Regression & (9) & (10) & (11) & (12) & (13) & (14) & (15) & (16) \\
\hline Equity & $\begin{array}{c}-0.0678 * \\
(-1.78)\end{array}$ & & $\begin{array}{c}-0.0708 * \\
(-1.76)\end{array}$ & & $\begin{array}{c}-0.0728 * \\
(-1.72)\end{array}$ & & $\begin{array}{c}-0.0723 * \\
(-0.59)\end{array}$ & \\
\hline $\begin{array}{l}\text { Equity * Stabilization } \\
\text { Loan-Only }\end{array}$ & $\begin{array}{c}\mathbf{0 . 0 5 1 7} * * \\
(\mathbf{2 . 3 5}) \\
0.0253 \\
(1.40)\end{array}$ & $\begin{array}{c}\text { 0.0516*** } \\
(2.36)\end{array}$ & $\begin{array}{c}\mathbf{0 . 0 5 1 4} * * \\
(\mathbf{2 . 1 2}) \\
0.0265 \\
(1.47)\end{array}$ & $\begin{array}{c}0.0512 * * \\
(2.13)\end{array}$ & $\begin{array}{c}\mathbf{0 . 0 4 9 6 *} \\
(\mathbf{1 . 9 4 )} \\
0.0264 \\
(1.46)\end{array}$ & $\begin{array}{c}\text { 0.0495* } \\
(1.95)\end{array}$ & $\begin{array}{c}\mathbf{0 . 0 5 7 4} * * \\
(\mathbf{2 . 1 0}) \\
0.0244 \\
(1.37)\end{array}$ & $\begin{array}{c}0.0572 * * \\
(2.11)\end{array}$ \\
\hline Loan-Only * Stabilization & $\begin{array}{c}0.0051 \\
(0.31)\end{array}$ & $\begin{array}{c}0.0050 \\
(0.30)\end{array}$ & $\begin{array}{c}0.0022 \\
(0.13)\end{array}$ & $\begin{array}{c}0.0021 \\
(0.13)\end{array}$ & $\begin{array}{c}0.0026 \\
(0.24)\end{array}$ & $\begin{array}{c}0.0025 \\
(0.14)\end{array}$ & $\begin{array}{c}0.0046 \\
(0.23)\end{array}$ & $\begin{array}{c}0.0044 \\
(0.22)\end{array}$ \\
\hline $\begin{array}{l}\text { Controls } \\
\text { R-Squared (overall) } \\
\text { F-test (p-value) }\end{array}$ & $\begin{array}{c}\text { Yes } \\
0.341 \\
0\end{array}$ & $\begin{array}{c}\text { Yes } \\
0.269 \\
0\end{array}$ & $\begin{array}{c}\text { Yes } \\
0.340 \\
0\end{array}$ & $\begin{array}{c}\text { Yes } \\
0.266 \\
0\end{array}$ & $\begin{array}{c}\text { Yes } \\
0.338 \\
0\end{array}$ & $\begin{array}{c}\text { Yes } \\
0.266 \\
0\end{array}$ & $\begin{array}{c}\text { Yes } \\
0.312 \\
0\end{array}$ & $\begin{array}{c}\text { Yes } \\
0.257 \\
0\end{array}$ \\
\hline
\end{tabular}

$*, * *$, and $* * *$ respectively indicate significance levels at $10 \%, 5 \%$, and $1 \%$ levels. 


\section{Figure 1}

Daily Market-Adjusted Returns with Respect to Issuing Price

Returns for each stock were adjusted by subtracting the market index return over the same period.

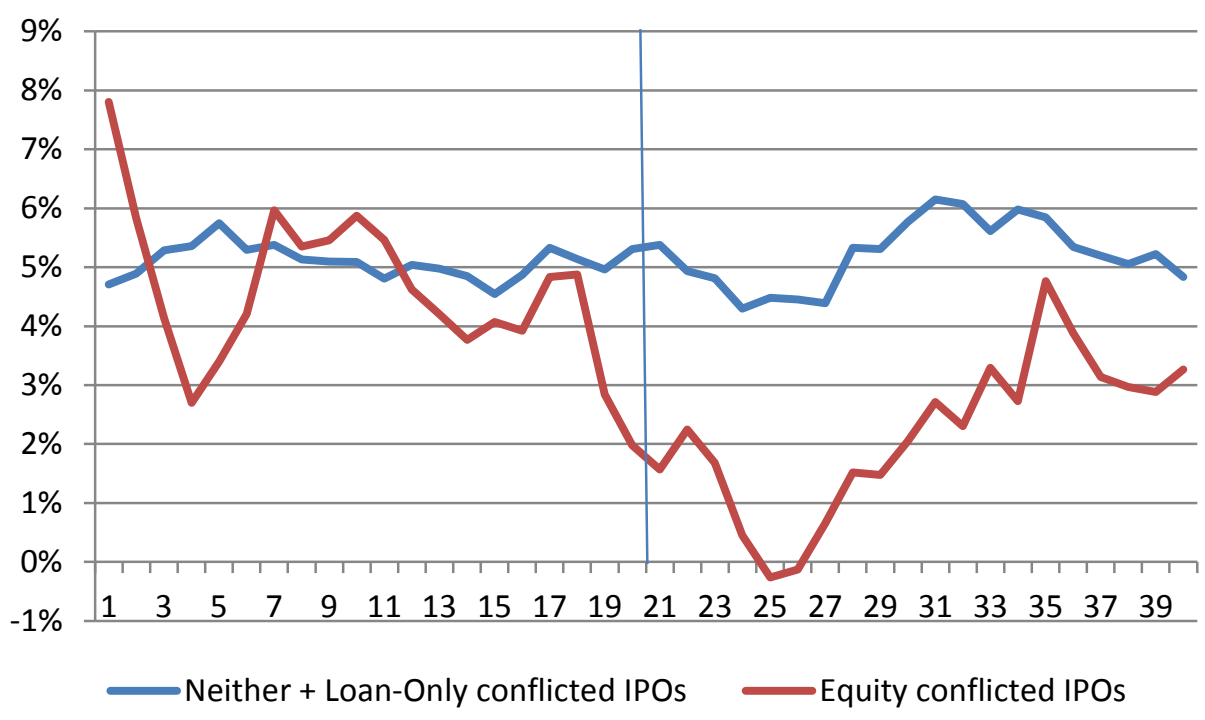




\section{INOVA}

\section{NOVA}

School

of Business

\& Economics

Shaping

powerful

minds

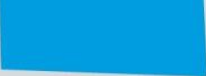

Nova School of Business and Economics

Faculdade de Economia

Universidade Nova de Lisboa

Campus de Campolide 1099-032 Lisboa PORTUGAL

Tel.: +351213801600

www.novasbe.pt 